\title{
The early Miocene lake of Foieta la Sarra-A in eastern Iberian Peninsula and its relevance for the reconstruction of the Ribesalbes-Alcora Basin palaeoecology
}

Sergio Álvarez-Parra, Joaquín Albesa, Soledad Gouiric-Cavalli, Plini Montoya, Enrique Peñalver, Josep Sanjuan, and Vicente D. Crespo

Acta Palaeontologica Polonica 66 (3), 2021: s013-s030 doi:https://doi.org/10.4202/app.00842.2020

The Ribesalbes-Alcora Basin (Castelló Province, Spain) contains two lower Miocene units that are rich in fossils. The Unit B contains oil-shale and laminated bituminous dolomicrite related to a palaeolake, whereas the Unit $\mathrm{C}$ is composed of sandstone and mudstone beds from distal deltaic and shallow lacustrine environments. The La Rinconada and San Chils localities from the Unit B have yielded a fossil assemblage of plants, molluscs, arthropods, and vertebrates, while the localities from the Unit $\mathrm{C}$ in the Campisano ravine (Araia/Mas d'Antolino outcrop) are rich in mammalian record. Here we study a new palaeolake deposit of laminated lacustrine limestone beds in the Unit C named Foieta la Sarra-A. This new locality has provided an assemblage of charophytes, terrestrial plants, molluscs, arthropods, and teleosteans. The latter represent the only known fish record from the Ribesalbes-Alcora Basin to date. Although the specimens are generally poorly preserved, the presence of soft-body preservation due to the action of microbial mats at the lake bottom allows considering the Foieta la Sarra-A locality as a Konservat-Lagerstätte. The Foieta la Sarra-A palaeolake had a different water chemistry compared to that represented in the Unit B. Its depth was about a few metres and the water level suffered periodic fluctuations. This new locality sheds light on the palaeoenvironmental dynamics of the Ribesalbes-Alcora Basin during the early Miocene and provides a new approach to the palaeoecological reconstruction of the basin.

Key words: Characeae, Poales, Gastropoda, Cladocera, Insecta, Teleostei, palaeoenvironment, taphonomy, palaeoecology, lacustrine basin, Neogene, Konservat-Lagerstätte, Spain.

Sergio Álvarez-Parra [sergio.alvarez-parra@ub.edu], Departament de Dinàmica de la Terra i de l'Oceà and Institut de Recerca de la Biodiversitat (IRBio), Facultat de Ciències de la Terra, Universitat de Barcelona, c/ Martí i Franquès s/n, 08028, Barcelona, Spain. Joaquín Albesa [joaquin.albesa@uv.es], Departament de Botànica i Geologia, Universitat de València, Dr. Moliner 50, 46100, Burjassot, Valencia, Spain; Museu Valencià d'Història Natural, L'Hort de Feliu, P.O. Box 8460, Alginet, 46230 Valencia, Spain. Soledad Gouiric-Cavalli [sgouiric@fcnym.unlp.edu.ar], Consejo Nacional de Investigaciones 
Científicas y Técnicas, División Paleontología Vertebrados, Museo de La Plata, Paseo del Bosque s/n, B1900FWA La Plata, Argentina. Plini Montoya [p.montoya@uv.es ], Departament de Botànica i Geologia, Universitat de València, Dr. Moliner 50, 46100, Burjassot, Valencia, Spain. Enrique Peñalver [e.penalver@igme.es], Instituto Geológico y Minero de España (Museo Geominero), c/ Cirilo Amorós 42, 46004, Valencia, Spain. Josep Sanjuan [js76@aub.edu.lb], Department of Geology, American University of Beirut-AUB, 11-0236 Beirut, Lebanon; Departament de Dinàmica de la Terra i de l'Oceà, Facultat de Ciències de la Terra, Universitat de Barcelona, c/ Martí i Franquès s/n, 08028, Barcelona, Spain. Vicente D. Crespo [vidacres@gmail.com] (corresponding author), Consejo Nacional de Investigaciones Científicas y Técnicas, División Paleontología Vertebrados, Museo de La Plata, Paseo del Bosque s/n, B1900FWA La Plata, Argentina; Museo Paleontológico de Alpuente, Av. San Blas 17, Alpuente, 46178 Valencia, Spain; Museu Valencià d'Història Natural, L'Hort de Feliu, P.O. Box 8460, Alginet, 46230 Valencia, Spain.

This is an open-access article distributed under the terms of the Creative Commons Attribution License (for details please see creativecommons.org), which permits unrestricted use, distribution, and reproduction in any medium, provided the original author and source are credited. 